\title{
Carcass characteristics of rabbits raised in the semi-arid region of Nigeria
}

\author{
Emmanuel Abayomi ROTIMI ${ }^{1 \mathscr{C}}$ (D), Hussaina Babba USMAN ${ }^{1}$ (D) Abduljalal Musa ALIYU $\mathbf{A}^{1}$ (D) \\ ${ }^{1}$ Department of Animal Science, Federal University Dutsinma, Katsina State. Nigeria.
}

MAKALE BILGISI / ARTICLE INFO

Makale tarihçesi / Article history:

DOI:10.37908/mkutbd.781072

Geliş tarihi /Received:22.08.2020

Kabul tarihi/Accepted:22.10.2020

\section{Keywords:}

Carcass, rabbit, sex.

Corresponding author: Emmanuel Abayomi
ROTIMI
$\square:$ earotimi@gmail.com

\section{ÖZET / A BSTR A C T}

\begin{abstract}
Aims: This study was carried out to investigate the carcass characteristics of male and female rabbits raised in the semi-arid condition.

Methods and Results: Twenty-four (24) rabbits, comprising of 12 bucks and 12 does, were used for this study. At 12 weeks of age, the rabbits were weighed and slaughtered. Parameters measured include; pre-slaughter weight (kg), hot carcass weight (g), four primal cut weights (shoulder, ribs, loin and rump), internal organs weight (liver, lungs, kidneys, hearts, stomach and intestines). Sex had non-significant effects on the preslaughter, hot carcass and the four primal cuts weights (shoulder, ribs, loin and rump).

Conclusion: Conclusively, sexual dimorphism existed in the weights of the internal organs such as; liver, lungs, kidneys and intestines where female rabbits had higher weights. However, the pre-slaughter, hot carcass, shoulder, rib, loin and rump weights were not significantly affected by sex, implying that any of the sex could be safely utilize for meat production. Pre-slaughter weight was positively correlated with the weights of hot carcass, shoulder, rib, loin and rump while negatively correlated with liver, stomach and intestine.
\end{abstract}

Significance and Impact of Study: Pre-slaughter weight could be use as selection criterion for improvement of carcass quality in rabbits.

Atıf / Citation: Rotimi EA, Usman HB, Aliyu AM (2021) Carcass characteristics of rabbits raised in the semi-arid region of Nigeria. MKU. Tar. Bil. Derg. 26(1) : 93-97. DOI: 10.37908/mkutbd.781072

\section{INTRODUCTION}

Rabbit meat is characterized by a high protein level, low fat and cholesterol contents and it is considered a healthful food product (Dalle Zotte, 2000). Carcass characteristics are affected by the mature body weight and the age of slaughter (Piles et al. 2000), hence selection for carcass traits in rabbits is an effective tool for improvement for meat type rabbits (Szendro et al., 2004).

Animal's age or slaughter weight (Dalle Zotte, 2002) and sex (Cavani et al., 2000) affect the carcass quality. Akıncı et al. (1998) reported that carcass characteristics of New Zealand White and California rabbits were found to be significantly affected by age $(P<0.01)$ but not affected by sex. Yakcin et al. (2006) also reported that female and male rabbits were not significantly different in the weights of fore legs, hind legs, ribs and loin. Likewise, Fayeye and Ayorinde (2008) reported that sex effect was not significant on carcass characteristics such as bledweight, dress carcass weight, dressing percentage, carcass length, gastrointestinal tract, pelt, external offal, edible offal, adipose fat and primal cuts. However, Murshed et al. (2014) observed that slaughter and carcass weights were affected by sex and they reported that males were slightly lower than in female rabbits. This study was therefore undertaken to evaluate and compare the carcass characteristics in sexes of rabbits slaughtered at 12 weeks under the semi-arid condition. 


\section{MATERIALS and METHODS}

\section{Description of The Experimental Location}

This study was carried out at the Rabbitary Unit of the Livestock Teaching and Research Farm, Federal University Dutsin-ma. Dutsin-ma is located within the Latitude of $12^{\circ} 26^{\prime} \mathrm{N}$ and Longitude of $7^{\circ} 29^{\prime} \mathrm{E}$ with annual mean temperature ranging from $29^{\circ} \mathrm{C}-31^{\circ} \mathrm{C}$ (Abaje et al., 2014).

\section{Experimental Animals and Management}

Twenty-four (24) rabbits, 12 bucks and 12 does, were used for this study. Rabbits were reared in separate wooden cages measuring $80 \mathrm{~cm} \times 50 \mathrm{~cm} \times 30 \mathrm{~cm}$ (length $x$ width $x$ height). The rabbits were fed with compounded diet containing $15 \%$ crude protein and 16 $\%$ crude fibre ad libitum. Fresh and green leaves of Tridax procumbens and Aspergillia africana were also given as available. Cooled clean was supplied ad libitum. The rabbits were dewormed and given necessary medications during the experimental period.

\section{Slaughtering and Dissection Procedure}

Rabbits were weighed before slaughtering at 12 weeks of age. The slaughtering and carcass dissections were carried out following the standard procedures of World Rabbit Science Association recommendations (Newton and Penman, 1990; Blasco et al., 1993). Each carcass was skinned, the abdomen opened, gut and internal organs were removed and weighed. The weights of liver, kidneys, heart and lungs were recorded. Carcass was divided to determine the weights of the four primal cuts (shoulders part, rib parts, loins part and rumps). Measurements were done using digital sensitive weighing scale.

\section{Data Collection and Analysis}

Pre-slaughter weight $(\mathrm{kg})$ : This was the live weight of each rabbit before slaughter. Hot carcass weight (g): This was the weight after slaughter and bleeding. Primal cuts weights (g). These include; shoulders part, rib parts, loins part and rumps part. Weights of the internal organs (g). These include; livers, lungs, kidneys, hearts, stomach and intestines. Data collected were analysed using SPSS statistical package (version 20.0). Results were presented as mean and standard error. Statistical significance of difference between bucks and does was assessed by Student t-tests. Pearson correlation coefficients between parameters were calculated using SPSS statistical package (version 20.0). The linear model fitted is shown below;

$Y_{i j k}=\mu+S_{i}+e_{i j k}$

$\begin{array}{lll}\text { Where, } & \\ \mathrm{Y}_{\mathrm{ijk}} & = & \text { Observations of dependent variable, } \\ \mu & = & \text { Overall mean of all observations, } \\ \mathrm{S}_{\mathrm{i}} & = & \text { Fixed effect of } \mathrm{i}^{\text {th }} \text { sex }(\mathrm{I}=1,2) \\ \mathrm{e}_{\mathrm{ijk}} & = & \text { Random error associated with each } \\ \text { record. } & \end{array}$

\section{RESULTS and DISCUSSION}

Table 1 shows the mean $( \pm S E)$ values of the carcass characteristics of the male and female rabbits. The mean pre-slaughter weight of bucks was $1.20 \pm 0.02 \mathrm{~kg}$ and $1.25 \pm 0.03 \mathrm{~kg}$ for does. The overall value was $1.23 \pm 0.02$ $\mathrm{kg}$. The hot carcass weights were $464.83 \pm 10.37 \mathrm{~g}$ and $518.17+30.07 \mathrm{~g}$ for bucks and does respectively with overall value of $491.50 \pm 16.21 \mathrm{~g}$. Sex had no significant $(P>0.05)$ effects on Pre-Slaughter, Hot Carcass, Shoulder, rib, loin and rump weights. Fayeye and Ayorinde (2008); Ghosh and Mandal (2008) and Yalçın et al. (2006) reported that sex had no significant effects on the slaughter weight of New Zealand rabbits at 11 weeks. This report is however contrary to the reports of other authors; Adelodun (2015) who recorded higher significant $(P<0.05)$ values female than male rabbits, while Murshed et al. (2014) and Trocino et al. (2002) recorded higher significant $(P<0.05)$ values male than female rabbits. The mean values obtained for preslaughter and hot carcass weights in this study were however lower than those obtained by Adelodun (2015) who reported $2220.60 \pm 71.2 \mathrm{~g}$ and $2088.70 \pm 11.5 \mathrm{~g}$ for male and female respectively on pre-slaughter weights and $2150 \pm 14.13 \mathrm{~g}$ and $2023.91 \pm 15.59 \mathrm{~g}$ for male and female respectively on hot carcass weights. Fernandez and Fraga (1996) suggested that differences in preslaughter and hot carcass weights might be attributed to the age, breeds and feeding conditions. There were no effects of sex on the results obtained for the primal cut parts in this study. This report is similar to the report of; Baiomy and Hassanien (2011); Fayeye and Ayorinde (2008); Ghosh and Mandal (2008); Murshed et al. (2014), who recorded non-significant difference effects of sex on different primal cuts of rabbit carcass. Yalçin et al. (2006) also observed that sex had no effects in the weights and percentages of fore legs, hind legs, ribs and loin. However, Adelodun (2015) observed that sex had significant $(P<0.05)$ effects on the loin weight of rabbits slaughtered at 11 weeks where male rabbits had higher significant $(\mathrm{P}<0.05)$ weights compared to female rabbits on; fore parts $(170.56 \pm 7.23 \mathrm{~g}$ and $160.47 \pm 9.55 \mathrm{~g}$ and hind parts $(398 \pm 8.04 \mathrm{~g}$ and $380.97 \pm 13.10 \mathrm{~g})$ loin (309.40 $\pm 11.50 \mathrm{~g}$ and $271.21 . \pm 12.85 \mathrm{~g}$ respectively). 
Table 1. Least square means $(\underline{+} \mathrm{SE})$ of the carcass characteristics of rabbits slaughtered at 12 weeks of age

\begin{tabular}{lccc}
\hline Parameters & Bucks & Does & Overall \\
\hline Pre-Slaughter Weight $(\mathrm{kg})$ & $1.20 \pm 0.02$ & $1.25 \pm 0.03$ & $1.23 \pm 0.02$ \\
Hot Carcass $(\mathrm{g})$ & $464.83 \pm 10.37$ & $518.17 \pm 30.07$ & $491.50 \pm 16.21$ \\
Shoulder $(\mathrm{g})$ & $65.58 \pm 1.23$ & $69.10 \pm 2.50$ & $67.34 \pm 1.40$ \\
Rib $(\mathrm{g})$ & $104.98 \pm 2.39$ & $103.11 \pm 4.37$ & $104.05 \pm 2.47$ \\
Loin $(\mathrm{g})$ & $141.37 \pm 2.02$ & $150.66 \pm 7.65$ & $146.01 \pm+3.97$ \\
Rump $(\mathrm{g})$ & $127.33 \pm 2.03$ & $137.30 \pm 6.31$ & $132.32 \pm 3.36$ \\
Hot carcass percentage & $40.79 \pm 1.53$ & $38.82 \pm 0.66$ & $39.80 \pm 0.84$ \\
\hline
\end{tabular}

Table 2 shows the means $( \pm S E)$ of the weights of the internal organs (g) of the rabbits. Sex had non-significant $(P>0.05)$ effects on the heart and stomach weights with overall weights (g) $2.79 \pm 0.05$ and $72.85 \pm 3.11$ respectively. Other authors also reported that sex had no significant effects on heart; Adelodun (2015) in the rabbits studied at 11 weeks of age, Murshed et al. (2014) and Yalçin et al. (2006) in rabbits at 11 weeks. Results obtained in this study revealed sexual dimorphism in the weights of liver, lungs, kidneys and intestine weights ( $g$ ) with bucks having higher significant $(P<0.05)$ weights than does $(32.77 \pm 0.84$ and $26.62 \pm 0.74,7.41 \pm 0.37$ and $5.75 \pm 0.11,8.92 \pm 0.23$ and $7.48 \pm 0.20,155.53 \pm 3.03$ and $121.83 \pm 2.73$ respectively). However, Yalçin et al. (2006) reported that there was no manifestation of sexual dimorphism in the liver, lungs and kidneys weights of rabbits slaughtered at 11 weeks of age. Ghosh and Mandal (2008) also reported non-significant sex effects on the weights of liver and kidneys of rabbits while Farghaly and El-Mahdy. (1999) recorded significant effect of sex on liver weight with females having significantly higher weight than the males. There was no significant difference in organ weights in male and female rabbits (Baiomy and Hassanien, 2011). The variations observed might be due to the breed, age or weight of the rabbits used in this study.

Table 2. Least square means $(\underline{+S E})$ of the internal organs of rabbits slaughtered at 12 weeks of age

\begin{tabular}{lccr}
\hline Parameters & \multicolumn{1}{c}{ Bucks } & Does & \multicolumn{1}{c}{ Overall } \\
\hline Livers $(\mathrm{g})$ & $26.62 \pm 0.74^{\mathrm{b}}$ & $32.77 \pm 0.84^{\mathrm{a}}$ & $29.69 \pm 0.71$ \\
Lungs $(\mathrm{g})$ & $5.75 \pm 0.11^{\mathrm{b}}$ & $7.41 \pm 0.37^{\mathrm{a}}$ & $6.58 \pm 0.23$ \\
Kidneys $(\mathrm{g})$ & $7.48 \pm 0.20^{\mathrm{b}}$ & $8.92 \pm 0.23^{\mathrm{a}}$ & $8.20 \pm 0.18$ \\
Heart $(\mathrm{g})$ & $2.70 \pm 0.07$ & $2.88 \pm 0.08$ & $2.79 \pm 0.05$ \\
Stomach $(\mathrm{g})$ & $69.55 \pm 4.59$ & $76.15 \pm 4.17$ & $72.85 \pm 3.11$ \\
Intestine $(\mathrm{g})$ & $121.83 \pm 2.73^{\mathrm{b}}$ & $155.53 \pm 3.03^{\mathrm{a}}$ & $138.68 \pm 3.18$ \\
\hline
\end{tabular}

a,bMean on the same row with different superscripts are significantly $(\mathrm{P}<0.05)$ different, $\mathrm{SE}=$ standard error

Table 3 shows the correlation coefficients among the carcass traits of rabbits slaughtered at 12 weeks of age. Upper diagonal shows the correlations coefficients in female rabbits (Table 3 ). Correlation values were positive and highly significant $(P<0.01)$ in the female rabbits (ranging from between $r=0.685$ to 0.990 ). Highest correlation value was obtained between hot carcass and rump while the lowest was recorded between shoulder and pre-slaughter weights. Values obtained in this study between pre-slaughter weight and the primal cuts were higher than the report of Yalçın et al. (2006).

The correlations coefficient values in male rabbits (Table $3)$ were highly significant $(P<0.01)$ except between preslaughter with rib and loin, shoulder with loin, while the value is negative and non-significant between shoulder and $\mathrm{rib}(r=-0.148 ; P>0.05)$. Highest value was obtained between hot carcass and rump $(r=0.978 ; P<0.01)$ and the lowest between pre-slaughter and rib $(r=0.052$; $\mathrm{P}<0.01)$. This is contrary with the report of Yalçın et al. (2006) who reported high value between breast and ribs weight and slaughter weights $(r=0.740)$.

Table 4 presents the correlation coefficients among the internal organs of rabbits slaughtered at 12 weeks of age. Upper diagonal shows the correlations coefficients in female rabbits (Table 4). Pre-slaughter weight was highly significant $(P<0.01)$ with heart weight $(r=0.851)$ while liver, stomach and intestine weights were negatively correlated with pre-slaughter weight $(r=-$ $0.488,-0.858$ and -0.477 respectively). However, in bucks, pre-slaughter weight with liver, kidneys, heart, stomach and intestine weights were all negatively 
correlated $(r=-0.735,-0.783,-0.131,-0.883$ and -0.689 respectively). This report is in disagreement with the report of Yalçın et al. (2006) who recorded highly significant correlation between slaughter weights with lungs, liver, kidneys and heart $(0.43,0.64,0.78$ and 0.46 respectively).

Table 3. Correlation coefficients among the carcass traits of rabbits slaughtered at 12 weeks

\begin{tabular}{lllllll}
\hline & PSW & Hot Carcass & Shoulder & Rib & Loin & Rump \\
\hline PSW & 1 & $0.904^{* *}$ & $0.685^{* *}$ & $0.709^{* *}$ & $0.850^{* *}$ & $0.871^{* *}$ \\
Hot Carcass & $0.671^{* *}$ & 1 & $0.896^{* *}$ & $0.910^{* *}$ & $0.980^{* *}$ & $0.990^{* *}$ \\
Shoulder & $0.842^{* *}$ & $0.673^{* *}$ & 1 & $0.974^{* *}$ & $0.901^{* *}$ & $0.931^{* *}$ \\
Rib & 0.052 & $0.589^{* *}$ & -0.148 & 1 & $0.921^{* *}$ & $0.939^{* *}$ \\
Loin & 0.176 & $0.790^{* *}$ & 0.180 & $0.888^{* *}$ & 1 & $0.988^{* *}$ \\
Rump & $0.756^{* *}$ & $0.978^{* *}$ & $0.693^{* *}$ & $0.600^{* *}$ & $0.762^{* *}$ & 1 \\
\hline
\end{tabular}

PSW $=$ Pre-slaughter weight, Upper diagonal $=$ does, lower diagonal $=$ bucks, ${ }^{* *}$ Correlation is significant $(\mathrm{P}<0.01)$.

Table 4. Correlation coefficients among the internal organs in rabbits slaughtered at 12 weeks

\begin{tabular}{llllllll}
\hline & PSW & Liver & Lungs & Kidneys & Heart & Stomach & Intestine \\
\hline PSW & 1 & $-0.488^{*}$ & $0.471^{*}$ & 0.149 & $0.851^{* *}$ & $-0.858^{* *}$ & $-0.477^{*}$ \\
Liver & $-0.735^{* *}$ & 1 & -0.141 & $0.668^{* *}$ & $-0.436^{*}$ & $0.433^{*}$ & 0.403 \\
Lungs & $0.428^{*}$ & -0.401 & 1 & 0.052 & 0.340 & $-0.818^{* *}$ & $-0.421^{*}$ \\
Kidneys & $-0.783^{* *}$ & $0.931^{* *}$ & $-0.433^{*}$ & 1 & -0.141 & -0.124 & -0.164 \\
Heart & -0.131 & 0.327 & $-0.795^{* *}$ & 0.150 & 1 & $-0.626^{* *}$ & -0.091 \\
Stomach & $-0.883^{* *}$ & $0.891^{* *}$ & $-0.638^{* *}$ & $0.930^{* *}$ & 0.334 & 1 & $0.569^{* *}$ \\
Intestine & $-0.689^{* *}$ & $0.652^{* *}$ & $-0.930^{* *}$ & $0.679^{* *}$ & $0.682^{* *}$ & $0.851^{* *}$ & 1 \\
\hline
\end{tabular}

Upper diagonal $=$ does, lower diagonal $=$ bucks, ${ }^{* *}$ Correlation is significant $(\mathrm{P}<0.01),{ }^{*}$ Correlation is significant $(\mathrm{P}<0.05), \mathrm{PSW}=$ Pre-Slaughter Weight, $\mathrm{HTC}=$ Hot Carcass

\section{CONCLUSIONS}

The pre-slaughter, hot carcass, shoulder, rib, loin and rump weights were not significantly affected by sex, implying that any of the sex could be safely utilize for meat production. There was positive correlation between pre-slaughter weight with the carcass qualities (hot carcass, shoulder, rib, loin and rump weights) for male and female rabbits, thus implies that pre-slaughter weight could be use as selection criterion for carcass quality in rabbits.

\section{ACKNOWLEDGEMENT}

This study was supported financially by Federal University Dutsin-ma (FUDMA), Katsina state, this is highly appreciated.

\section{CONFLICT OF INTEREST}

The authors declare no conflict of interest

\section{AUTHOR'S CONTRIBUTIONS}

The contribution of the authors is equal.

\section{REFERENCES}

Abaje IB, Sawa BA, Ati OF (2014) Climate Variability and Change, Impacts and Adaptation Strategies in DutsinMa Local Government Area of Katsina State, Nigeria. Journal of Geography and Geology 6(2): 103-112.

Adelodun OF (2015) Sexual Dimorphism in the Carcass Traits of Rabbits in Humid Tropics. International Journal of Livestock Research 5(5): 30-37.

Akıncı Z, Poyraz Ö, Akçapınar H, Evogliyan N (1998) The effects of genotype, sex and age on some slaughter traits and carcass characteristics of New Zealand White and California Rabbits. Journal of Lalahan Livest. Res. Inst. 38: 84-102.

Blasco A, Ouhayoun J, Masoero G (1993) Harmonization of criteria and terminology in rabbit meat research. World Rabbit Science 1(1): 3-10.

Baiomy AA, Hassanien HHM (2011) Effect of breed and sex on carcass characteristics and meat chemical composition of New Zealand white and Californian rabbits under upper Egyptian environment. Egyptian Poultry Science 31(2): 275-284. 
Cavani C, Bianchi M, Lazzaroni C, Luzi F, Minelli G, Petracci M (2000) Influence of type of rearing, slaughter age and sex on fattening rabbit: II. Meat quality. In: Proceeding of the $7^{\text {th }}$ World Rabbit Congress, Spain, Vol A: p. 567-572.

Dalle Zotte A (2000) Main factors influencing the rabbit carcass and meat quality. Proc. of the $7^{\text {th }}$ World Rabbit Congress, Valencia, Spain. 1-32.

Dalle Zotte A (2002) Perception of rabbit meat quality and major factors influencing the rabbit carcass and meat quality. Livestock Production Science 75: 11-32.

Farghaly HM, El-Mahdy MRM (1999) Genetic and nongenetic factors affecting live, carcass and non-carcass traits of New Zealand White rabbits in Egypt. Indian Journal of Animal Science 69(8): 596-603.

Fayeye TR, Ayorinde KL (2008) Effects of weaning litter size and sex on post weaning bodyweight, mortality and carcass characteristics of domestic rabbit in the humid tropics. In: Proceeding of $9^{\text {th }}$ World Rabbit Congress - June 10-13, 2008 - Verona - Italy. P. 15351538

Fernandez C, Fraga MJ (1996) The effect of dietary fat inclusion on growth, carcass characteristics, and chemical composition of rabbits. Journal of Animal Science 74: 2088-2094.

Ghosh N, Mandal L (2008) Carcass and meat quality traits of rabbits (Oryctolagus cuniculus) under warm-humid condition of West Bengal, India. Livestock Research for Rural Development 20 (9).
Murshed HM, Shishir SR, Rahman SME, Deog-Hwan OH (2014) Comparison of carcass and meat characteristics between male and female indigenous rabbit of Bangladesh. Bangladesh Journal of Animal Science 43 (2): 154-158.

Newton R, Penman S (1990) A Manual for Small-Scale Rabbit Production. Oxford and IBH Publishing Co Pvt Ltd, Calcutta.

Piles M, Blasco A, Pla M (2000) The effect of selection for growth rate on carcass composition and meat characteristic of rabbits. Meat Science, 54: 347-355.

SPSS (011) Statistical Package for the Social Sciences. User's Guide: Statistics, Version 20.0. Institute, Inc., Cary, C, USA.

Szendro Z, Romvári R, Nagy I, Andrassy-Baka G, Metzger S, Radnai I, Biro-Nemeth E, Szabo A, Vigh Z, Horn P (2004) Selection of Pannon White rabbits based on computerised tomography. In Proc: 8th World Rabbit Congress, September 7-10, 2004 Puebla, Mexico. P. 175-180.

Trocino A, Xiccato G, Queaque PI, Sartori A (2002) Effect of transport duration and sex on carcass and meat quality of growing rabbits. In: Proceeding of 2nd Rabbit Congress of the America, Cuba. p. 232-235.

Yalçin S, Onbasilar EE, Onbasilar I (2006) Effect of sex on carcass and meat characteristics of New Zealand White rabbits aged 11 weeks. Asian-Australasian Journal of Animal Sciences 19: 1212- 1216. 